\title{
Factors Linking Declining Reef Health Ecosystem to Poverty in Lagonoy Gulf, Eastern Bicol, Philippines
}

\author{
Antonino B. Mendoza, Jr. (Corresponding author) \\ Bicol University Tabaco Campus, Tabaco City, Albay, Philippines \\ E-mail: antox.mendoza@gmail.com \\ Plutomeo M. Nieves \\ Bicol University Tabaco Campus, Tabaco City, Albay, Philippines \\ Michael C. Borejon \\ Bicol University Tabaco Campus, Tabaco City, Albay, Philippines
}

Received: April 20, 2021 Accepted: December 8, 2021 Published: December 21, 2021

doi: 10.5296/jsss.v8i2.18548 URL: https://doi.org/10.5296/jsss.v8i2.18548

\begin{abstract}
This paper provided likely linkage between poverty and reef health status in Lagonoy Gulf. It showed that fishers are poor as reflected by their weekly income ranging from $\mathrm{PhP} 2,500.00$ to $<500.00$ averaging $\mathrm{PhP} 1,214.00$ which is way below the $\mathrm{PhP} 3,596$ week $^{-1}$ poverty threshold for Bicol Region. Population density in coastal municipalities is highest in Albay with 512 ind. $\mathrm{km}^{-2}$ and least in Catanduanes with 325 ind. $\mathrm{km}^{-2}$. Fishers are relatively ageing with mean age of 48 years and average fishing experience of 29 years. Majority only reached or finished primary level, and only $6 \%$ reached college. Five out of six do not own boat and gears, showing financial incapacity. Hook and lines were used by $66 \%$ of the fishers while, nets comprised $32 \%$. Living coral cover declined from 1993 to 2018 by almost $25 \%$. High dependence to coastal resources, high demand for seafood, destructive gears, lack of supplemental sources of income, low educational background, lack of skills, low income are identified contributory factors to habitat degradation. With the declining reef health and fish catch, fishers that are living below poverty threshold are more likely to become poorer because the reef's capacity to provide goods and services is lost.
\end{abstract}

Keywords: Reef health, reef destruction, resiliency and marine protected area 


\section{Introduction}

Poverty is in most cases linked with natural resources degradation, this is because of the poor sector heavy dependence to natural resources and environment for their survival needs, (Barbier, 2010; Bene, 2003; Angelsen 1999; Broad 1994). Much more so with the tendency of this sector to be concentrated in fragile areas and often with critical environmental conditions, the degree of dependence will worsen degradation of the natural resources (Barbier, 2010; Creel, 2003).

The Philippines being an archipelagic nation, most of the families living below poverty threshold are concentrated in coastal areas and according to Philippine Statistics Authority (2019), fishermen is the poorest sector, with Bicol as among the regions in the Philippines with the highest poverty incidence and magnitude.

With its proximity to reef ecosystem and easy access to coastal resources, exploitation is evident. In the report of Licuanan et al., (2017) on the status of coral reefs of the Philippines, Bicol reef areas are among with low hard coral cover in Luzon Island, and are mostly attributed to anthropogenic stresses (Magdaong et al., 2014). For living hard coral cover in Lagonoy Gulf, downtrend was noted from 1994 - 2004 with 10\% decline in Marine Protected Area (MPA) (David et al., 2005) while from 1994 to 2018 an average decline of 25\% was detected Mendoza et al., (in prep). Furthermore, Soliman et al., (2008), noted that fish catch composition in Lagonoy Gulf from 1994 to 2004 had significantly change from predominantly carnivore to herbivore and planktivore. Mangrove forest cover in the Philippines on the other hand, also declined by almost 50\% from 1918 to 2010 (Long et al., 2014; Long and Giri, 2011) mostly due to fish culture expansions and coastal development (Primavera, 2000). Compounding these issues is the sector's vulnerability to climate and disaster risks. The impact of climate change and natural disasters including effects of typhoons has overturned gains in the sector to the detriment of small farmers and fisherfolks.

Gulf's coastline measures $225 \mathrm{~km}$, has an average coastal population density of $552 \mathrm{~km}^{-2}$, from 165 coastal barangays with fishing as the main source of income. The registered fishers are around 14,000 (BFAR, 2017) which is roughly 7\% of the total coastal population. Fishermen are living way below than the average family income of PhP 3,596 week ${ }^{-1}$ for Bicol region. Aside from this, $70 \%$ do not have secondary or supplemental sources of income. Fishing gears are mostly small entangling nets and hand lines catching mainly small demersal fishes (Nieves et al., in prep.).

With this, insights and relationship between poverty and reef ecosystem will be a crucial input in the resiliency of reef ecosystem utilizing fisher demographics and reef ecological data to provide science-based management measures to improve reef's services.

\section{Methodology}

\subsection{Study Area}

Lagonoy Gulf (Fig. 1) is located at the Bicol Peninsula on southern Luzon Island. It is bounded by 165 coastal Barangays belonging to 14 Municipalities and 1 City, from three 
Provinces (namely: Albay, Camarines Sur and Catanduanes). Albay Province accounted for the majority of the number of Barangays (51\%) while Catanduanes and Camarines Sur accounted for $25 \%$ and $24 \%$, respectively (see Table 1). Estimated coastal population as of 2017 is 253,528 of which $58 \%$ are from Albay while the other $25 \%$ and $17 \%$ are contributed by Camarines Sur and Catanduanes, respectively. Fishing is the main livelihood in these areas where majority of the catch are demersal reef fishes and the rest ventured on offshore handline tuna fishing.

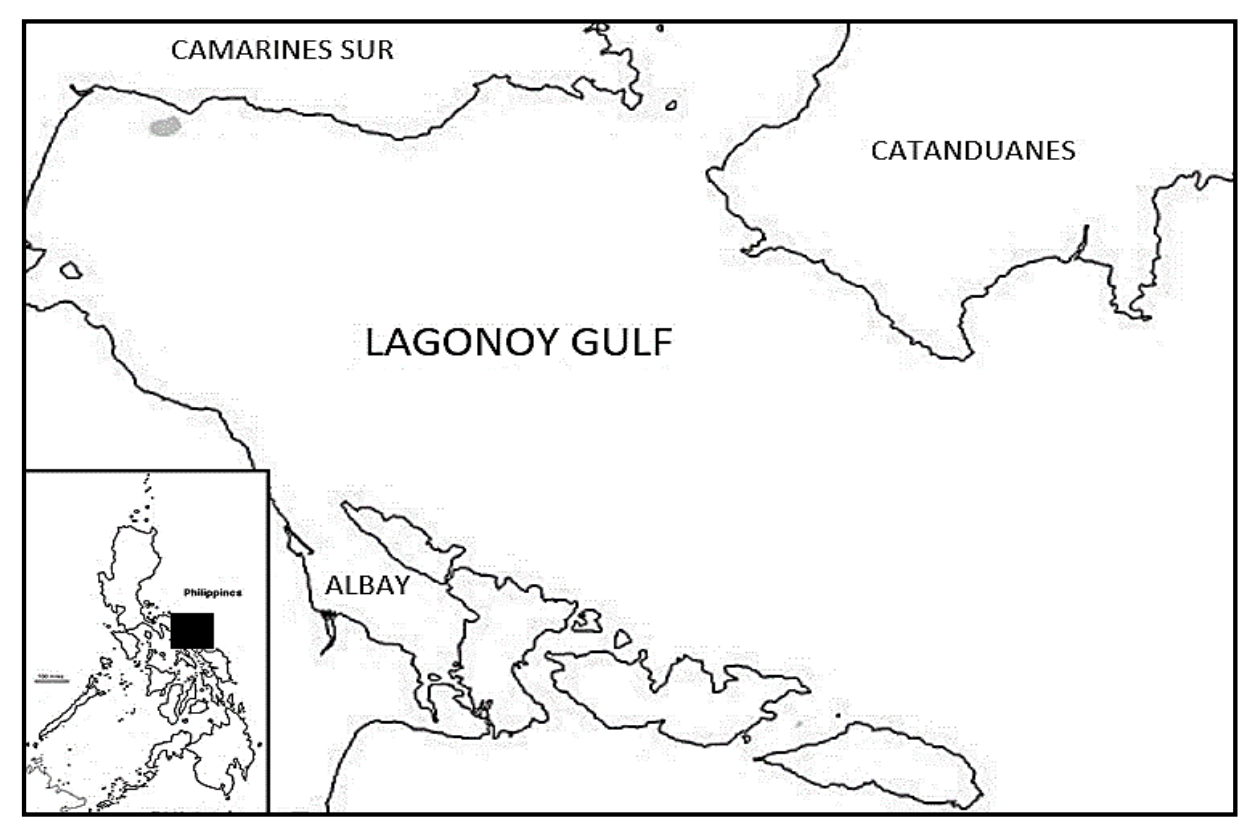

Figure 1. Map showing Lagonoy Gulf and the provinces of Albay, Camarines Sur and Catanduanes in the Bicol Region. Inset photo is the Philippine map showing the location of Lagonoy Gulf in the Pacific seaboard

\subsection{Research Framework}

This study was based on the frame shown in figure 2. It showed a straight forward relationship between fishermen and status of reef ecosystem. It demonstrates that fishermen which are solely dependent on marine resources for food and income have a tendency to do overfishing due to increasing demand and need for money to support their families. The worst of it is that in their pursuit for more catch most fishers resort to the use of illegal and destructive gears that may result to loss of biodiversity, increase of algae and increase in dead corals. These may lead to reef destruction which will redound to loss of income and livelihood. Thus, making another cycle of poverty (Cinner 2009; Creel, 2003)

\subsection{Data Collection}

Data on fishers' registration were obtained from BFAR database on National Program for Municipal Fisherfolk Registration or FishR (http://frs.bfar.da.gov.ph) and Municipal Fishing Vessel and Gear Registration System or BoatR (boatr.bfar.da.gov.ph) for 2017. A total of 10 respondents from each of the 16 selected Barangays were employed to generate needed fisheries information such as fishers' profile, fishing and fishing gears used, catch and income 


\section{Macrothink Institute ${ }^{\mathrm{TM}}$}

data, among others. These respondents were randomly chosen from the list of fishers from each of the Barangay. Relevant socio-demographic information was derived from Department of Agriculture - Bureau of Fisheries and Aquatic Resources (DA-BFAR), concerned Local Government Units (LGU's), Philippine Statistics Agency (PSA) and other relevant reports and publications available. For information on the status of reef ecosystem, this paper utilized results of the reef status survey (Mendoza et al., in prep), socio-eco survey (Nieves et al., in prep) and coral juvenile survey (Bista et al., in prep). These studies were part of the research project on status and resiliency of coral reefs in Lagonoy Gulf.

Table 1. Basic fishing demographic characteristics of Lagonoy Gulf

\begin{tabular}{|c|c|c|c|c|c|c|c|c|}
\hline Province & Municipality & Population & Land Area $\left(\mathrm{km}^{-2}\right)$ & $\begin{array}{l}\text { Income } \\
\text { Class }\end{array}$ & No. of Reg. Fishers & $\%$ Fisher & Pop. Density $\left(\mathrm{km}^{-2}\right)$ & No. of Coastal Barangay \\
\hline \multirow{6}{*}{ ALBAY } & BACACAY & 40,651 & 83.00 & $\begin{array}{c}\text { below } \\
10 \mathrm{~K} / \text { month }\end{array}$ & 1959 & 4.8 & 489.77 & 31 \\
\hline & MALIIIPOT & 5,890 & 6.00 & same & 430 & 7.3 & 981.67 & 5 \\
\hline & MALINAO & 10,466 & 17.00 & same & 723 & 6.9 & 615.65 & 5 \\
\hline & RAPU-RAPU & 21,032 & 104.83 & same & 2961 & 14.1 & 200.63 & 19 \\
\hline & TABACO & 46,857 & 29.32 & same & 1649 & 3.5 & 1598.12 & 13 \\
\hline & TTWI & 22,205 & 47.00 & same & 662 & 3.0 & 472.45 & 12 \\
\hline \multirow{6}{*}{ CAM SUR } & CARAMOAN & 6,169 & 38.00 & same & 3541 & 12.4 & 162.34 & 5 \\
\hline & LAGONOY & 6,443 & 42.95 & same & 775 & 12.0 & 150.01 & 6 \\
\hline & PRESENTACION & 16,436 & 109.57 & same & 833 & 5.1 & 150.00 & 11 \\
\hline & SAGNAY & 16,461 & 28.88 & same & 1200 & 7.3 & 569.98 & 8 \\
\hline & SAN JOSE & 13,476 & 14.65 & same & 612 & 4.5 & 919.86 & 7 \\
\hline & TIGAON & 3,707 & 5.00 & same & 169 & 4.6 & 741.40 & 2 \\
\hline \multirow{3}{*}{ CATANDUANES } & BATO & 7,609 & 13.54 & same & 1805 & 23.7 & 561.96 & 7 \\
\hline & SAN ANDRES & 15,627 & 78.77 & same & 1980 & 12.8 & 198.39 & 14 \\
\hline & VIRAC & 20,499 & 42.44 & same & 1325 & 6.46 & 483.01 & 20 \\
\hline
\end{tabular}

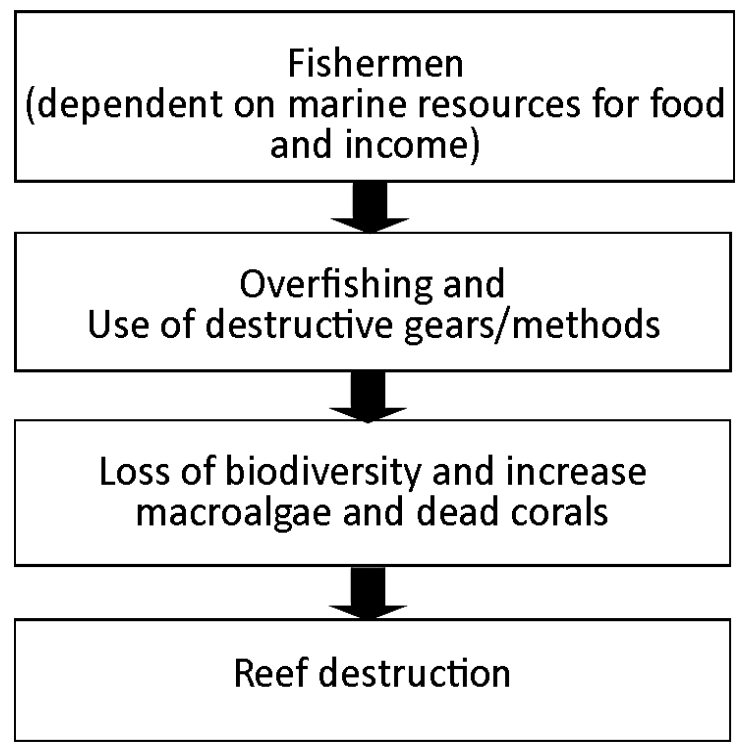

Figure 2. Process flow showing relationship between fishermen and status of reef ecosystem

\section{Results and Discussion}

Lagonoy Gulf is generally a fishing community, except for some coastal Barangays of mainland Tabaco City where fishers are below $2 \%$ of coastal population, but in Island 
Barangays, registered fishers are relatively high which is up to $10 \%$ of the coastal population. This is because most of the population in the coastal areas in the mainland prefer to work in commercial establishments in the City rather than fishing, same also with the municipality of Tiwi where fishers were just $3 \%$ of the total coastal population due to the presence of a Geothermal Power Plant which provide employment in the area (Table 1). This scenario is understandable as working in commercial establishments warrants security and tenure of work. Key informant Interviews with fishers revealed that all of them do not want their children to be engage in fishing due to uncertainties in fishing such as declining catch, increasing prices of fishing inputs (i.e., gasoline, labor, ice, etc.), and increasing fishing associated risks because recent fishing grounds are becoming more distant. This was also similar to the accounts of Fabinyi (2012) in his case studies of the fishers in the Philippines. Also, this can be illustrated in Figure 2 wherein young adult fishers constitute less than $10 \%$ of the overall number of fishers in the Gulf.

However, most of fishers still chose fishing even if alternative livelihood is available. This is consistent with the findings of Mualil et al., (2013); Martin et al., (2013); Pollnac et al., (2001). This can be assumed on the age bracket of Lagonoy fishers where $50 \%$ belong to 40-59 years old and mean age of 48 years old (fig. 3), with an average 29 years fishing experience. Reasonably, fishing has been the "way of life" for these people that even alternate sources of income are available, they will not quit fishing (Pollnac et al., 2001; Mualil et al., 2013). The low engagement of young fishers can be attributed to the educational attainment of the young generation. Due to free education in the Philippines (RA 6655 or the Free Public Secondary Education Act of 1988 and RA 10931 or the Universal Access to Quality Tertiary Education Act) they were able to finish high school, which is the minimum requirement for work or some even have reached college or have college degree.

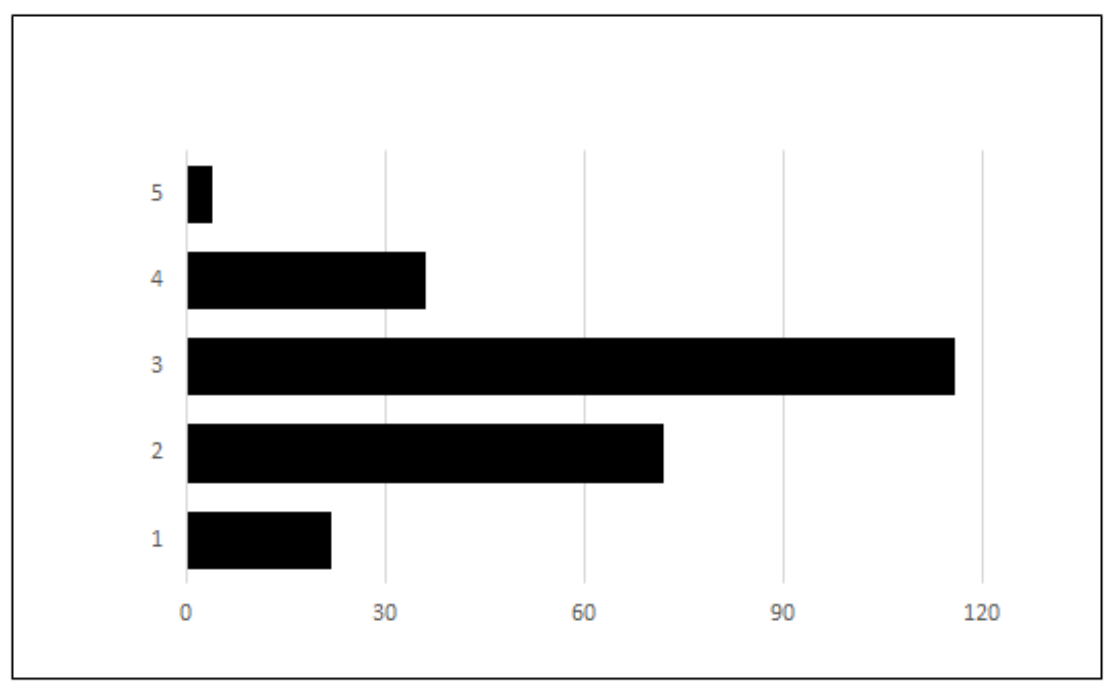

Figure 3. Age distribution of the fishers in Lagonoy Gulf

Municipal coastal land area ranged from $5 \mathrm{~km}^{2}$ to $110 \mathrm{~km}^{2}$, in Tigaon and Presentacion respectively. While the population densities ranged from 150 ind. $\mathrm{km}^{-2}$ to 1600 ind. $\mathrm{km}^{-2}$ in the municipality of Lagonoy and Tabaco City, respectively. It was noticed that the places 
considered as business centers such as Tabaco City and its nearby municipalities like Tiwi, Bacacay and Rapu-rapu, population densities are higher (Table 1) which is consistent with the bioecological theory of human development (Bronfenbrenner \& Evans, 2000). The opportunities available in these areas attract people to reside permanently or temporary for their livelihood and income.

Figure 4 shows the fishers profile in terms of years of experience into fishing. More than a quarter of the fishermen have been fishing from 21-30 years, while those with 11-20- and 31-40-years fishing experiences comprised about 50\%, and those that have been fishing for more than 41 years were relatively higher at $18 \%$. Only $10 \%$ have done fishing for less than 10 years. This would depict how long the fishers are engaged into fishing and how dependent are the coastal communities on fishing for food, income and livelihood, with at least $1-2$ family members were engaged into full time fishing.

Figure 5 reveals the one important factor why fishermen in the Philippines are possibly trap in poverty. This is due to their low educational background, which is the result of the lack of education also of their parents and their parents' parents - which can be traced back to the Spaniard's colonization. More than $61 \%$ of the respondents have taken and/or have finished only primary education while $1 / 3$ have entered and/or graduated from secondary education and very few $(6 \%)$ have entered college but did not complete their degree. The low education background of fishers, results to lack of skills and ability to own assets (Bene and Heck, 2005; and Bene, 2003) like houses, fishing implements and others. This could also explain why $71 \%$ of the respondents do not have other sources of income, only $29 \%$ have additional income. Consequently, the low income will not be enough to provide basic needs to support like education of their children and needed nutritional requirement to their families (Mualil, 2013). This now creates "trap" in the realm of poverty (Barrett and Swallow 2006, Bene 2003). Interestingly, greater majority of the respondents owned their houses, although it is public land because these are nearshore areas, however, most of the houses are not concrete that makes it vulnerable to strong winds and storm surges.

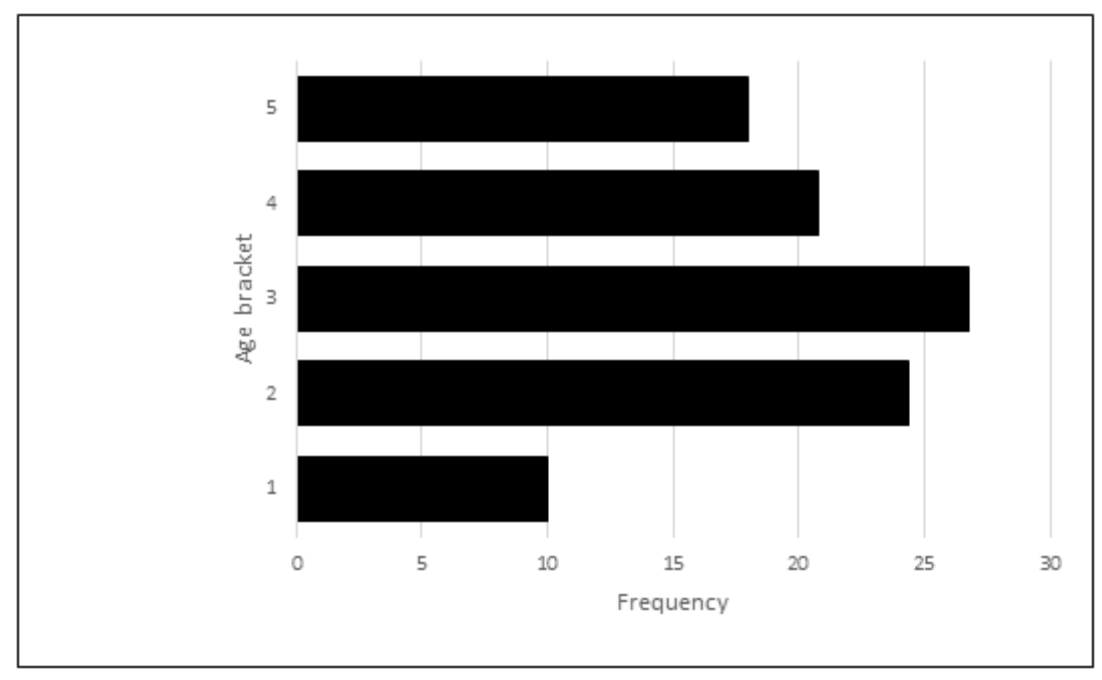

Figure 4. Years of fishing experience in Lagonoy Gulf 


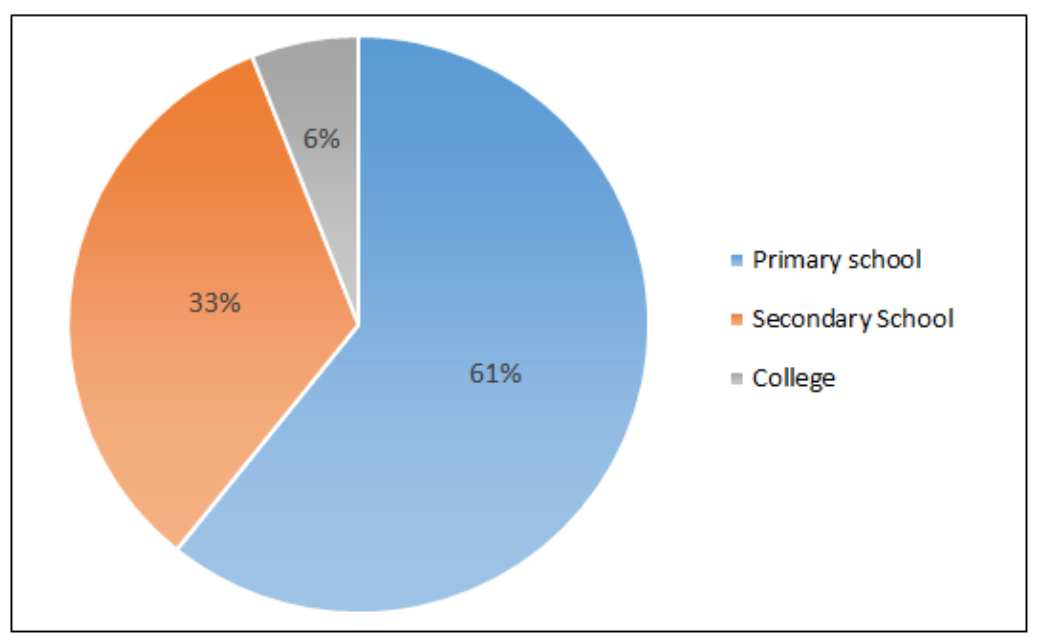

Figure 5. Educational attainment of the fishers in Lagonoy Gulf

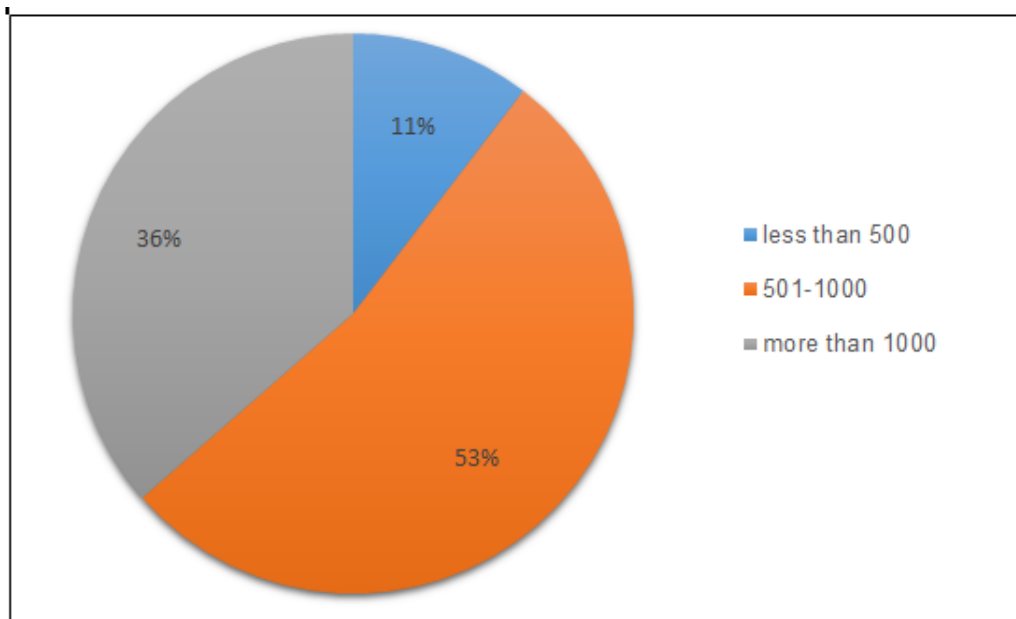

Figure 6. Distribution of weekly income of fishermen in Lagonoy Gulf

Lagonoy Gulf fishers' income is three times below the PhP 3,596.00 week $^{-1}$ poverty threshold for Bicol. Fishers' income ranged from PhP 2500.00 to less than 500 week $^{-1}$ with an average income of $\mathrm{PhP} 1,214.00$, with $36 \%$ earning more than 1000.00 week $^{-1}$, while $53 \%$ having an income of less than $\mathrm{PhP} 1000.00$ and the rest having less than 500.00 week $^{-1}$ (Fig 6). Obviously, these fishers cannot afford to provide basic needs for their families. This is because 5 out of 6 fishermen do not own boat and gear. Fisher and boat/gear registration analysis revealed a 6:1:1 - fisher:boat:gear ratio in Lagonoy Gulf, this would have impact on the sharing of fishing income. Usually, boat and gear are 1 part of the income and the rest is divided among the fishers. This situation is worst for those fishing reef associated demersal fishes, where catch is usually few kilos (nil to $8 \mathrm{~kg} \mathrm{trip}^{-1}$ ) as compared to those engaged in fishing small and large pelagic species where catches can reach up to about $1,000 \mathrm{~kg}$. This is comparable with the recent estimates from the study of Mualil et al., (2014) on 44 coastal municipalities in the Philippines for small-scale fishers averaging $5.3 \mathrm{~kg}_{\text {trip }}{ }^{-1}$ fisher $^{-1}$. 
The country's official definition of poverty is based on Republic Act (RA) 8425 or the Social Reform and Poverty Alleviation Act of 1997. The poor are those individuals and families whose incomes fall below the poverty threshold or those who cannot afford to provide their minimum basic needs for survival and security in a sustained manner. Income is therefore the primary measure of poverty, which is compared with a given threshold determined according to basic needs.

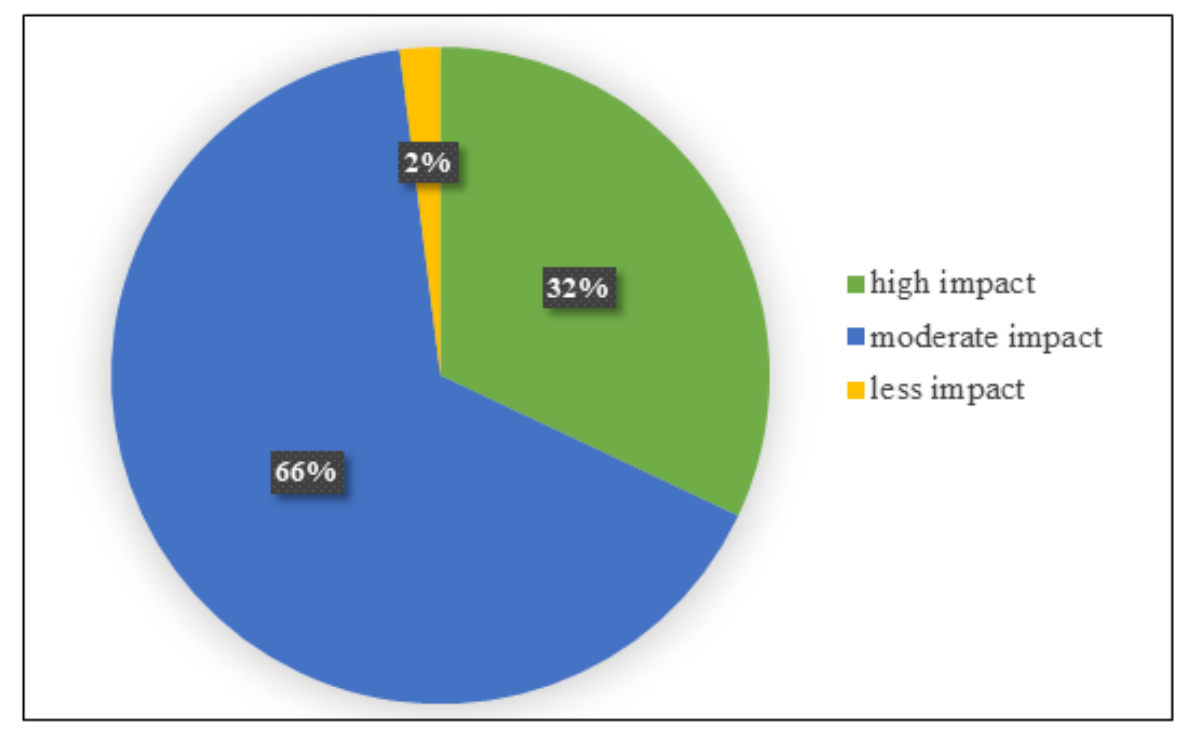

Figure 7. Classification of fishing gears based on impact to coral reef

With the high poverty incidence along the coastal zones of Lagonoy Gulf, reef resources dependence vis a vis its utilization is high, as exemplified by type of gear used (Fig. 7) and number of registered fishers (Table 1). As ascribed by Cinner (2009), poverty is an important factor on the exploitation of marine resources especially in tropical developing countries like the Philippines. With the high demand for seafood, it can result to overharvesting (Creel, 2003). Furthermore, alongside with the heavy exploitation is the use of destructive fishing gears that affect reef habitats and catching juvenile fishes (Cinner, 2009; Pauly et al., 1989). In Lagonoy Gulf, seine and entangling nets were the widely used high impact destructive gears to coral reefs and seagrass beds comprising $66 \%$, while $32 \%$ were considered to have moderate impacts like spears and bottom set longlines. Only $2 \%$ of the gears used in the Gulf were considered to have less impact to reef habitats such as hook and lines, and traps. Not discounting the fact that there still existing use of illegal means of fishing which are more destructive to corals and nearby critical habitats. Sixty-six percent $(66 \%)$ of the respondents recognized that presence of blast and compressor fishing, use of poisonous substances, encroachment of commercial fishers and use of other illegal gears have dramatically impacted health status of corals. Consequently, this decline had also affected quantity and quality of their fish catch with $88 \%$ of the fishers believed that these are the reason for the decline of fish catch which had forced $91 \%$ them to fish away from the coast. These observations were similar to the study of McManus et al., (1997) on the impacts of 
destructive fishing on coral cover and its recovery rate. Use of destructive methods such as cyanide and blast fishing could contribute from $0.4 \%$ to $1.4 \%$ annum $^{-1}$, respectively. With the fishing area farther away from the coast, input in fishing is also higher making it difficult for poor fishers to venture. With this, most fishers were constrained to exploit the coastal areas despite declining catch and increasing effort (Muallil et al., 2013; Pauly et al., 1989). With more than $70 \%$ of the fishers in the Gulf that solely depend on fishing for income and livelihood, exploitation leading to destruction of habitats is threatening (Cinner 2009; Pauly et al., 1989).

A study based on catch trends has suggested that the condition of small-scale fisheries in the Philippines has been deteriorating with severe depletion of fish stocks to the level indicative of biological and economic overfishing since the 1990s (Muallil et al. 2014). Lagonoy Gulf, have also been experiencing high fishing pressures and have reached the overexploited level (Silvestre et al., 1995; Soliman et al., 2008; Soliman et al., 2009; Olano et al., 2018). Side by side with this is the decline of reef habitats such as corals and seagrass beds. For living hard coral cover, downtrend was noted from 1994 - 2004 with 10\% decline of Marine Protected Area (MPA) (David et al., 2005) while from 2004 to 2018 decrease was almost $20 \%$ and from 1993 to 2018 an average decline of $25 \%$ was detected (Mendoza et al., in prep) (fig 8). Furthermore, Soliman et al., (2008), noted that fish catch composition from 1994 to 2004 had significantly change from predominantly carnivore to herbivore and planktivore. The decline was attributed mostly to fishery activities however not discounting impacts of natural phenomena (David et al., 2005; Mendoza et al., 2000; Mendoza et al., in prep.). With the declining coral reef health coupled with declining fish catch, fishers are that are already living below poverty threshold are more likely to be poorer (Cinner 2009) because the capacity of the reefs to provide goods and services and buffer seasonal and periodic hardships is being eroded. Reef degradation is stripping many of the benefits on which the poor depend (Whittingham et al., 2003).

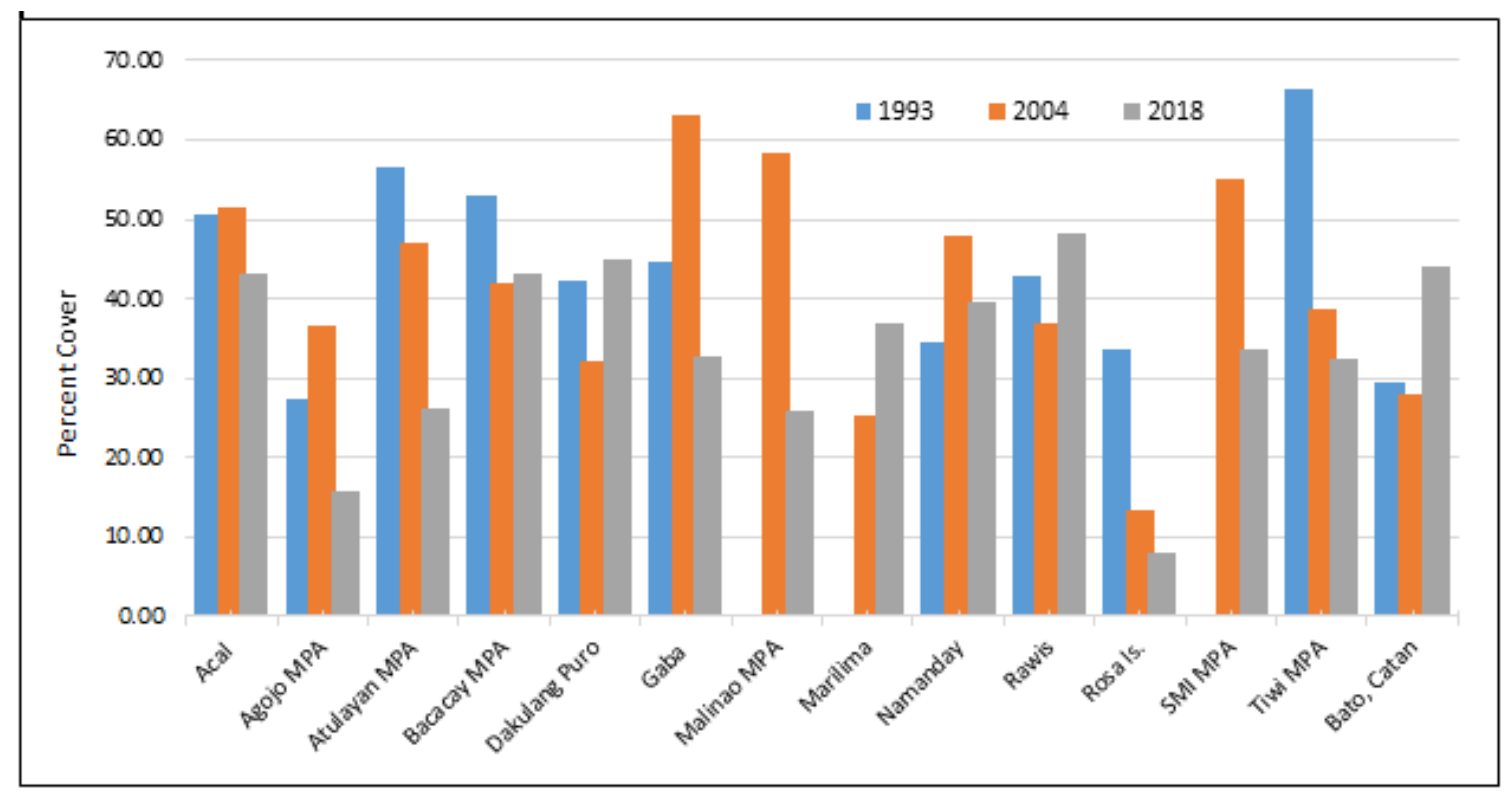

Figure 8. Trend of mean live coral cover in Lagonoy Gulf 


\section{Conclusion}

Despite their significant contribution to the country, fisherfolks remain to be one of the poorest sectors in the Philippines, (PSA, 2017). Factors such as high dependence to coastal resources, high demand for seafood, use destructive gears, lack of supplemental sources of income, low educational background, lack of skills, low income are contributory factors to overexploitation leading to habitat degradation. The aforementioned factors indicate interrelationships between poverty and status of reef ecosystems in Lagonoy Gulf. Furthermore, study showed that Lagonoy Gulf fisherfolks are poor and are their being poor is contributory to the decline of reef habitats. However, with the decreasing population of young fishermen due to the free education, pressure on fishery resources is perceived to ease down, and with the increasing educated coastal populace, use of destructive gears will likely to decline (Mualil et al., 2013) and resource protection is likely to prosper (Bradecina 2008). The welfare function of small-scale fisheries, namely, their capacities to provide labor (livelihood) and cash income to resource-poor households, should be understood, and the appropriate macroeconomic conditions for rent maximization and redistribution are fulfilled (Béné et al. 2010).

\section{Recommendations}

With the foregoing findings of the study, it is recommended that responsible local government units and national agencies should take a look at the conditions of these coastal families and make necessary livelihood and science-based support management mechanisms that would take them away from fishing at the reef ecosystem. As such, training on other livelihood opportunities should be formulated. Information dissemination should be done regularly to keep them informed of the importance of protecting and conserving natural resources.

\section{Acknowledgement}

This project is funded by Philippine Council for Agriculture and Aquatic Resources Research and Development of the Department of Science and Technology (PCAARRD-DOST). We also thank the support and assistance of Local Government Units (LGUs) in the provinces of Albay, Camarines Sur and Catanduanes bordering Lagonoy Gulf, partner agencies (i.e., BFAR), and other individuals and entities who helped much in the accomplishment of the work.

Ethics Statement. No animal or human studies were carried out by the authors.

\section{References}

Angelsen, A. (1997). The Poverty-Environment Thesis: Was Brundtland Wrong? In Forum for Development Studies (Vol. 24, No. 1, pp. 135-154). Taylor \& Francis Group. https://doi.org/10.1080/08039410.1997.9666053

Barbier, E. B. (2010). Poverty, development, and environment. Environment and Development Economics, 635-660. https://doi.org/10.1017/S1355770X1000032X 
Barrett, C. B., \& Swallow, B. M. (2006). Fractal poverty traps. World development, 34(1), 1-15. https://doi.org/10.1016/j.worlddev.2005.06.008

Béné, C. (2003). When fishery rhymes with poverty: a first step beyond the old paradigm on poverty in small-scale fisheries. World development, 31(6), 949-975. https://doi.org/10.1016/S0305-750X(03)00045-7

Bene, C., \& Heck, S. (2005). Fisheries and the millennium development goal: solutions for Africa.

Béné, C., Hersoug, B., \& Allison, E. H. (2010). Not by rent alone: analyzing the pro-poor functions of small-scale fisheries in developing countries. Development Policy Review, 28(3), 325-358. https://doi.org/10.1111/j.1467-7679.2010.00486.x

Bista, J. K. B., Mendoza, A. B., \& Borejon, M. C. (in prep) Density of coral juvenile survey in Lagonoy Gulf with emphasis to MPA vs nonMPAs.

Bradecina, R. G. (2008). Socioeconomic Conditions and Governance in the Atulayan Bay Marine Protected Area. Kuroshio Science, 2(1), 85-92.

Broad, R. (1994). The poor and the environment: friends or foes? World development, 22(6), 811-822. https://doi.org/10.1016/0305-750X(94)90055-8

Bronfenbrenner, U., \& Evans, G. W. (2000). Developmental science in the 21st century: Emerging questions, theoretical models, research designs and empirical findings. Social development, 9(1), 115-125. https://doi.org/10.1111/1467-9507.00114

Cinner, J. E. (2009). Poverty and the use of destructive fishing gear near east African marine protected areas. Environmental Conservation, 321-326.

https://doi.org/10.1017/S0376892910000123

Creel, L. (2003). Ripple effects: Population and coastal regions (pp. 1-7). Washington, DC: Population reference bureau.

David, D. N., Camaya, A. P., Buella R. B., \& Mendoza, A. B. J. (2005). Assessment of Coral Reefs in Lagonoy Gulf. In V. S. Soliman \& R. R. Dioneda (Eds.), Resources and Social Assessment of Lagonoy Gulf. Tech Report submitted to DA-BFAR.

Fabinyi, M. (2012). Fishing for fairness: Poverty, morality and marine resource regulation in the Philippines (pp. 227). ANU Press. https://doi.org/10.22459/FF.01.2012

Licuanan, A. M., M. Reyes, K. Luzon, M. A. Chan, \& Licuanan, W. Y. (2017). Initial Findings of the Nationwide Assessment of Philippine Coral Reefs. Philippine Journal of Science, 146(2), 179-187.

Long, J. B., \& Giri, C. (2011). Mapping the Philippines' mangrove forests using Landsat imagery. Sensors, 11(3), 2972-2981. https://doi.org/10.3390/s110302972

Long, J., Napton, D., Giri, C., \& Graesser, J. (2014). A mapping and monitoring assessment of the Philippines' mangrove forests from 1990 to 2010. Journal of Coastal Research, 30(2), 
260-271. https://doi.org/10.2112/JCOASTRES-D-13-00057.1

Magdaong, E. T., Fujii, M., Yamano, H., Licuanan, W. Y., Maypa, A., Campos, W. L., ... \& Martinez, R. (2014). Long-term change in coral cover and the effectiveness of marine protected areas in the Philippines: a meta-analysis. Hydrobiologia, 733(1), 5-17. https://doi.org/10.1007/s10750-013-1720-5

Martin, S. M., Lorenzen, K., \& Bunnefeld, N. (2013). Fishing farmers: Fishing, livelihood diversification and poverty in rural Laos. Human Ecology, 41(5), 737-747. https://doi.org/10.1007/s10745-013-9567-y

McManus, J. W., Reyes Jr, R. B., \& Nanola Jr, C. L. (1997). Effects of some destructive fishing methods on coral cover and potential rates of recovery. Environmental management, 21(1), 69-78. https://doi.org/10.1007/s002679900006

Mendoza, A. B, Jr., Asejo, R. B. Jr., Borejon, M. C., Bradecina S. R. B. (in prep), Current status and resiliency of coral reefs in Lagonoy Gulf with notes on marine protected areas in Lagonoy Gulf.

Mendoza, A. B., Soliman, V. S., David, D. N., \& Buella, J. R. (2000). Assessment of marine fishery reserves and sanctuaries in Bicol for local government planning. Paper presented during the $5^{\text {th }}$ National Symposium in Marine Science. October 17-19, 1999. UP MSI, Diliman, Q.C., 6 pp.

Muallil, R. N., Cleland, D., \& Aliño, P. M. (2013). Socioeconomic factors associated with fishing pressure in small-scale fisheries along the West Philippine Sea biogeographic region. Ocean \& coastal management, 82, 27-33. https://doi.org/10.1016/j.ocecoaman.2013.04.013

Muallil, R. N., Mamauag, S. S., Cababaro, J. T., \& HO Arceo (2014). Catch trends in Philippine small-scale fisheries over the last five decades: The fishers' perspectives. Marine Policy, 47, 110-117. https://doi.org/10.1016/j.marpol.2014.02.008

Nieves, P. M., Mendoza, A. B., Borejon, M. C. (in prep). Socio-Economic Condition, Poverty and Fishers Resilience in Lagonoy Gulf.

Olaño, V. L., Lanzuela, N. S., \& Paredes, K. S. (2018). Assessment of Fishery Resources in Lagonoy Gulf, Philippines. The Philippine Journal of Fisheries, 25(1), 62-76. https://doi.org/10.31398/tpjf/25.1.2017C0007

Pauly, D., Silvestre, G., \& Smith, I. R. (1989). On development, fisheries and dynamite: a brief review of tropical fisheries management. Natural Resource Modeling, 3(3), 307-329. https://doi.org/10.1111/j.1939-7445.1989.tb00084.x

Pollnac, R. B., Pomeroy, R. S., \& Harkes, I. H. (2001). Fishery policy and job satisfaction in three Southeast Asian fisheries. Ocean \& Coastal Management, 44(7-8), 531-544. https://doi.org/10.1016/S0964-5691(01)00064-3

Primavera, J. H. (2000). Development and conservation of Philippine mangroves: institutional issues. Ecological Economics, 35(1), 91-106. https://doi.org/10.1016/S0921-8009(00)00170-1 


\section{Macrothink

Silvestre, G., Luna, C., Soliman, V., \& Garces, L. (1995). Resource and Ecological Assessment of Lagonoy Gulf. ICLARM Technical Report.

Soliman, V. S., Bobiles, R. U., \& Yamaoka, K. (2008). Overfishing of three siganid species (family: Siganidae) in Lagonoy gulf, Philippines. Kuroshio Science, 2, 145-150.

Whittingham, E., Campbell, J., \& Townsley, P. (2003). Poverty and reefs. IMM Limited.

http://frs.bfar.da.gov.ph accessed June 2018

boatr.bfar.da.gov.ph accessed June 2018

http://www.psa.gov.ph accessed Dec. 2019.

https://psa.gov.ph/content/farmers-fishermen-and-children-consistently-posted-highest-povert y-incidence-among-basic - accessed March 5, 2020

https://www.bulatlat.com/2018/02/26/fisheries-code-worsened-poverty-fisherfolk-20-years-fi sherfolk-group - accessed March 5, 2020

\section{Copyright Disclaimer}

Copyright for this article is retained by the author(s), with first publication rights granted to the journal.

This is an open-access article distributed under the terms and conditions of the Creative Commons Attribution license (http://creativecommons.org/licenses/by/4.0/). 